\title{
METODE PEMBELAJARAN YANG DIGUNAKAN PAUD (PENDIDIKAN ANAK USIA DINI) PERMATA BUNDA
}

\author{
Eci Sriwahyuni \& Nofialdi
}

IAIN Batusangkar, Sumatera Barat, Indonesia

\begin{abstract}
LEARNING METHOD USED BY PAUD (EARLY CHILDHOOD EDUCATION) PERMATA BUNDA. In this qualitative research, the reseachers described the instructional methods which were applied by Early Childhood Education (PAUD) Permata Bunda. The documentation, observation, and interview were used as instruments to collect the data. The results revealed that Early Childhood Education of Permata Bunda used the instructional methods 1) playing blocks method; 2) memorizing method; 3) role play method; 4) playing music and sing method; 5) playing card method; and 6) experimental method. The results implicated to the teachers should have strong motivation to upgrade students' knowledge and created the creative instructional media to apply the instructional methods which were organized.
\end{abstract}

Keywords: Learning Method, Early Childhood Education (PAUD), Permata Bunda

\section{A. Pendahuluan}

Akhir-akhir ini perhatian pemerintah cukup besar terhadap Pendidikan Anak Usia Dini (PAUD). Salah satu buktinya dengan digelarnya rapat kerja oleh Direktorat Jenderal Pendidikan Anak Usia Dini dan Pendidikan Masyarakat, Kemdikbud dengan tema "Pengelolaan BOP DAK PAUD dan Program PAUD DIKMAS" yang diadakan di Ballroom Mercure Hotel \& Convention Ancol. Wartanto (Kemdikbud, 24 April 2016) melaporkan rapat kerja yang digelar selama tiga hari tersebut, 12-14 April 2016 memiliki tujuan di antaranya mempercepat eksekusi pencairan dana PAUD yang mencapai Rp. 2.28 triliun.

Menurut Dirjen PAUD, Dikmas Harris Iskandar, Ph.D, bagi daerah yang ingin maju dan berdaya saing, maka berinvestasilah dengan membangun 44 PAUD berkualitas. "Insya Allah ke depan akan memiliki SDM berkualitas dan 
mampu diandalkan, PAUD menjadi prioritas pembangunan human capital di Indonesia dan juga dunia. PAUD diangkat derajatnya masuk ke dalam salah satu Sustainable Development Goals (SDG)" (Kemdikbud, 24 April 2016). Tujuan SDG, Dirjen menambahkan, antara lain memastikan kualitas pendidikan minimal pra SD merupakan target yang harus dicapai seluruh negara sebelum 2030. "Masih lama memang, tapi kalau tidak disiapkan dari sekarang kita akan kedodoran. Itulah pentingnya minimal pra SD itu, anakanak mendapat layanan PAUD," ujar Harris (Kemdikbud, 24 April 2016).

Selain rapat kerja tersebut, pemerintah pun sebelumnya telah mengeluarkan Peraturan Menteri Pendidikan dan Kebudayaan Republik Indonesia Nomor 137 Tahun 2014 tentang Standar Nasional Pendidikan Anak Usia Dini. Dengan adanya peraturan tersebut dan didukung dengan pendanaan yang mencapai angka Rp. 2.28 triliun merupakan bukti nyata dari perhatian pemerintah terhadap Pendidikan Anak Usia Dini.

Anak usia dini merupakan periode awal yang paling mendasar dalam pertumbuhan dan perkembangan kehidupan manusia. Pada masa ini ditandai oleh berbagai periode penting yang menjadi dasar dalam kehidupan anak yang selanjutnya. Salah satu periode menjadi ciri masa usia dini adalah golden ages atau periode usia emas. Periode usia emas pada anak usia dini ditandai dengan munculnya masa eksplorasi, masa identifikasi/imitasi, masa peka, masa bermain dan masa trozt alter atau masa membangkang (Suharti, 2013).

Anak usia dini adalah individu yang sedang mengalami proses pertumbuhan dan perkembangan yang sangat pesat, sehingga dikatakan sebagai golden age, yaitu usia yang berharga dibanding usia-usia selanjutnya (Isjoni, 2010). Oleh sebab itulah pendidikan anak usia dini seharusnya menjadi perhatian utama, tidak saja pemerintah tetapi setiap lapisan masyarakat.

Pendidikan Anak Usia Dini adalah wahana bermain sambil belajar yang penuh keceriaan dan kebebasan. Dengan demikianmemungkinkan anakuntuk berekspresi dan mengembangkan bakat, minat dan kreatifitasnya. Sekaligus juga mendapatkan pengetahuan keterampilan serta pengembangan sikap perilaku anak dalam suasana yang menyenengkan (Agustina, dkk, 2013). Menurut Peraturan Mentri Pendidikan dan Kebudayaan, Pendidikan Anak Usia Dini adalah upaya pembinaan yang ditujukan kepada anak sejak lahir sampai usia 6 (enam) tahun yang dilakukan melalui pemberian rancangan pendidikan untuk membantu pertumbuhan dan perkembangan jasmani dan rohani agar anak memiliki kesiapan dalam memasuki pendidikan lebih 
lanjut (Permendikbud, nomor 137 tahun 2014).

Dari beberapa konsep tentang Pendidikan Anak Usia Dini tersebut dapat disimpulkan bahwa Pendidikan Anak Usia Dini merupakan usaha membina anak yang berumur di bawah 6 tahun dengan metode bermain sambil belajar guna menggali dan mengembangkan bakat, minat dan kreatifitasnya. Banyak konsep dan fakta yang ditemukan memberikan penjelasan bahwa periode keemasan pada masa usia dini ketika semua potensi anak berkembang paling cepat (Hasan, 2009). Para ahli pendidikan sepakat bahwa "periode keemasan tersebut hanya berlangsung satu kali sepanjang rentang kehidupan manusia". Hal ini menunjukkan bahwa betapa meruginya suatu keluarga, masyarakat, dan bangsa jika mengabaikan masamasa penting yang berlangsung pada anak usia dini (Warniti, dkk, 2014).

Berdasarkan data lapangan yang peneliti peroleh dari Kepala PAUD Permata Bunda yang terletak di Nagari Cubadak, Kecamatan Lima Kaum, Batusangkar bahwa "masih kurangnya kesadaran masyarakat akan pentingnya Pendidikan Anak Usia Dini, banyak dari masyarakat yang menganggap bahwa Pendidikan Anak Usia Dini hanya tempat untuk bermainmain, menghabiskan waktu saja tanpa hasil apa-apa. Oleh sebab itu banyak para orang tua kurang berminat untuk mendaftarkan anak-anak mereka ke PAUD" (Hasil wawancara dengan Kepala PAUD Permata Bunda, Gusti Indri Yeni, S.Pd, 11 April 2016).

Kendatipun begitu Gusti Indri Yeni, S.Pd selaku Kepala PAUD Permata Bunda merasa terpanggil untuk mensosialisasikan kepada masyarakat akan pentingnya Pendidikan Anak Usia Dini ini. Salah satu usaha yang bisa beliau lakukan adalah membantu peserta didik dalam mengembangkan berbagai potensi baik fisik maupun psikis yang meliputi nilai agama dan moral, motorik, kognitif, bahasa, serta sosial emosional sehingga anak siap untuk memasuki pendidikan dasar. Dengan menghasilkan lulusan yang berkualitas dan siap melanjutkan ke Sekolah Dasar, secara tidak langsung PAUD Permata Bunda bisa memberi bukti kepada masyarakat akan pentingnya Pendidikan Anak Usia Dini (Hasil wawancara dengan Kepala PAUD Permata Bunda, Gusti Indri Yeni, S. Pd, 11 April 2016).

Menurut Yeni (Kepala PAUD Permata Bunda, 11 April 2016) untuk menciptakan lulusan yang siap melanjutkan ke Sekolah Dasar dibutuhkan usaha yang sungguh-sungguh dari para pendidik dalam merangkul anak untuk bermain sambil belajar yang menyenangkan. Setiap pendidik harus memperlakukan anak-anak tersebut seperti anaknya sendiri, oleh sebab $\sqrt{46}$ itu Yeni menerapkan panggilan "Bunda" kepada semua guru. Dengan 
panggilan bunda tersebut anak akan merasa dekat dengan gurunya seperti orang tua sendiri, begitu juga sebaliknya. Selain itu menurut Yeni, metode pembelajaran juga merupakan hal terpenting untuk diperhatikan, karena metode pembelajaran yang tidak menarik akan menimbulkan kebosanan bagi peserta didik. Yeni bersama rekannya berusaha membuat metode pembelajaran yang menarik yang dituangkan dalam Rencana Program Pembelajaran Harian (RPPH) dan Rencana Program Pembelajaran Mingguan (RPPM) (Hasil wawancara dengan kepala PAUD Permata Bunda, Gusti Indri Yeni, S.Pd, 11 April 2016).

Tujuan pembelajaran akan tercapai bila pendidik bisa menggunakan metode yang tepat. "metode adalah jalan yang harus dilalui untuk mencapai suatu tujuan" (Agung, 2012). Oleh sebab itu menurut peneliti penting dilakukan penelitian mengenai metode pembelajaran PAUD yang diterapkan di PAUD Permata Bunda.

Kajian dalam penelitian ini didukung dengan temuan Sari (2012) yang menyimpulkan bahwa melalui permainan sains dengan menggunakan metode demonstrasi dapat meningkatkan kemampuan sains anak kelompok B di Taman Kanak-kanak Tri Bina payakumbuh. Penemuan selanjutnya oleh Sinaga (2010) yang menyimpulkan bahwa lagu anak-anak bisa digunakan sebagai media untuk belajar kosa kata, pengalaman memperkaya kata, mengekspresikan bahasa juga bisa digunakan sebagai media yang mendukung penyampaian pesan. Membuat proses belajar menjadi menyenangkan. Kadang guru menemukan kesulitan dalam membuat lirik sebuah lagu. Mereka tidak gampang dalam memadupadankan kata dalam menciptakan sebuah lagu sesuai dengan tema. Kesulitan lainnya adalah dalam mencocokkan lagu dengan melodi. Temuan selanjutnya yang mendukung kajian ini adalah Prasetyo, dkk (2011) yang menyimpulkan bahwa metode pengajaran yang paling tepat diterapkan untuk mengajarkan kemampuan membaca pada anak usia dini adalah Metode Glenn Doman, dan penerapan metode Glenn Doman untuk mengajarkan kosa kata baru bagi anak usia dini di Pos PAUD Mutiara Semarang menghasilkan data bahwa pada Tahap I diperoleh rata pencapaian sebesar $61.4 \%, 62.3 \%$ pada Tahap II, dan 66.5\% pada Tahap III.

Dari beberapa hasil penelitian tersebut, menurut peneliti kajian tentang metode pembelajaran PAUD yang diterapkan di PAUD Permata Bunda penting dilakukan agar mengetahui metode apa saja yang digunakan agar pembelajaran di PAUD menjadi efektif. Penelitian ini peneliti lakukan dalam rangka mengeksplor metode pembelajaran terkini yang diterapkan di 
PAUD agar menjadi bahan kajian seluruh PAUD di Batusangkar, Tanah Datar pada khususnya dan Indonesia pada umumnya.

Penelitian ini adalah penelitian kualitatif dengan menggunakan instrumen observasi, dokumentasi, dan wawancara (Emzir, 2011). Metode observasi, peneliti gunakan untuk mengamati secara langsung metode pembelajaran di PAUD Permata Bunda. Fokus peneliti adalah metode pembelajaranyangditerapkan di PAUD PermataBunda. MenurutSukmadinata (2006) observasi merupakan suatu teknik atau cara mengumpulkan data dengan jalan mengadakan pengamatan terhadap kegiatan yang sedang berlangsung.

Metode dokumentasi digunakan untuk mengumpulkan data tentang metode pembelajaran di PAUD Permata Bunda. Pengumpulan data dengan metode dokumentasi dilakukan dengan mengumpulkan perangkat pembelajaran berupa Rencana Program Pembelajaran Harian (RPPH) dan Rencana Program Pembelajaran Mingguan (RPPM).

Metode wawancara peneliti gunakan untuk mengumpulkan data sekilas informasi mengenai PAUD Permata Bunda. Pihak yang diwawancarai adalah Kepala PAUD Permata Bunda. Kemudian wawancara kedua peneliti lakukan untuk mengumpulkan data mengenai metode pembelajaran yang diterapkan di PAUD Permata Bunda. Pihak yang diwawancarai adalah salah seorang guru PAUD Permata Bunda. Menurut Sudjana (2000) wawancara adalah proses pengumpulan data atau informasi melalui tatap muka antara pihak penanya (interviewer) dengan pihak yang ditanya atau penjawab. Metode wawancara yang digunakan dalam penelitian ini adalah wawancara tidak terstruktur. Data yang diperoleh melalui metode wawancara ini juga untuk melengkapi data yang didapat lewat metode observasi, sehingga data yang diperoleh lebih lengkap dan mendalam. Dengan demikian, metode wawancara ini merupakan triangulasi pengumpulan data atas data observasi. Menurut Molelong (2002) triangulasi adalah teknik pemeriksaan keabsahan data yang memanfaatkan sesuatu yang lain. Teknik triangulasi yang paling banyak digunakan ialah pemeriksaan melalui sumber lainnya.

\section{B. Pembahasan}

\section{Metode Pembelajaran PAUD}

Metode adalah jalan yang harus dilalui untuk mencapai suatu tujuan (Agung, 2011). Pendapat lain mengatakan bahwa metode adalah cara yang dalam berkerjanya merupakan alat untuk mencapai tujuan kegiatan

48 (Moeslichatoen, 2004). Sedangkan pengertian metode yang tertulis dalam 
kompetensi supervisi akademik yang dikeluarkan oleh Direktorat Tenaga Kependidikan merupakan upaya untuk mengimplementasikan rencana yang sudah disusun dalam kegiatan nyata agar tujuan yang telah disusun tercapai secara optimal. Metode digunakan untuk merealisasikan strategi yang telah ditetapkan. Strategi menunjuk pada sebuah perencanaan untuk mencapai sesuatu, sedangkan metode adalah cara yang dapat digunakan untuk melaksanakan strategi. Dengan demikian suatu strategi dapat dilaksanakan dengan berbagai metode (Direktorat Tenaga Kependidikan, 2008). Dari beberapa pendapat tersebut metode adalah cara yang digunakan untuk melaksanakan strategi atau perencanaan agar tujuan yang telah disusun tercapai secara maksimal.

Pembelajaran adalah kegiatan yang bertujuan untuk membelajarkan siswa (Sanjaya, 2007). Pembelajaran adalah suatu sistem atau proses membelajarkan subjek didik atau pembelajar yang direncanakan atau didesain, dilaksanakan, dan dievaluasi secara sitematis agar subjek didik atau pembelajar dapat mencapai tujuan-tujuan pembelajaran secara efektif dan efisien (Sulhan, 2006). Menurut Peraturan Menteri Pendidikan dan Kebudayaan pembelajaran adalah proses interaksi antar anak didik, antara anak didik dan pendidik dengan melibatkan orangtua serta sumber belajar pada suasana belajar dan bermain di satuan atau program PAUD (Permendikbud, nomor 137 tahun 2014). Dari beberapa pendapat tersebut, pembelajaran merupakan kegiatan atau proses interaksi sesama peserta didik, antara peserta didik dan pendidik dengan melibatkan orang tua serta sumber belajar untuk mencapai tujuan-tujuan pembelajaran secara efektif dan efisien.

Metode pembelajaran adalah metode yang harus dilalui untuk mencapai tujuan yang telah ditetapkan pada setting pembelajaran. Metode pembelajaran adalah metode yang diterapkan oleh guru terhadap anak didiknya di dalam kelas dalam mencapai tujuan pembelajaran (Slameto, 2010). Penetapan tujuan pembelajaran merupakan syarat mutlak bagi guru dalam memilih metode yang akan digunakan di dalam menyajikan materi pengajaran. Tujuan pembelajaran merupakan sasaran yang hendak dicapai pada akhir pengajaran, serta kemampuan yang harus dimiliki siswa. Sasaran tersebut dapat terwujud dengan menggunakan metode-metode pembelajaran (Direktorat Tenaga Kependidikan, 2008). Jadi metode pembelajaran merupakan cara yang digunakan guru atau pendidik dalam menyajikan materi kepada peserta didik untuk mencapai tujuan-tujuan pembelajaran secara efektif dan efisien sesuai dengan perencanaan sebelumnya. 
Menurut Peraturan Menteri Pendidikan dan Kebudayaan, Pendidikan Anak Usia Dini adalah upaya pembinaan yang ditujukan kepada anak sejak lahir sampai usia 6 (enam) tahun yang dilakukan melalui pemberian rancangan pendidikan untuk membantu pertumbuhan dan perkembangan jasmani dan rohani agar anak memiliki kesiapan dalam memasuki pendidikan lebih lanjut (Permendikbud, nomor 137 tahun 2014). Mutiah (2010) mengungkapkan bahwa anak usia dini merupakan kelompok anak yang berada dalam proses pertumbuhan dan perkembangan yang bersifat unik, artinya memiliki pola pertumbuhan dan perkembangan fisik (koordinasi motorik kasar dan halus), kecerdasan (daya pikir, daya cipta), sosial emosional, bahasa dan komunikasi. Masa anak usia dini ini tidak akan terlulang lagi. Jadi sia-sia rasanya bila orang tua tidak mengoptimalkan pendidikan anak-anak mereka sejak usia dini. Sehingga jika pada masa kritis, rangsangan/stimulasi tersebut tidak diberikan maka besar kemungkinan tugas-tugas perkembangan kognitif tidak dapat dicapai secara optimal atau bahkan mengalami keterlambatan (Martini, 2006).

Dari beberapa pengertian di atas tentang metode, pembelajaran dan Pendidikan Anak Usia Dini, dapat disimpulkan bahwa metode pembelajaran untuk Pendidikan Anak Usia Dini adalah cara yang digunakan guru atau pendidik dalam menyajikan materi kepada peserta didik yaitu anak yang berumur di bawah 6 tahun untuk mencapai tujuan-tujuan pembelajaran secara efektif dan efisien sesuai dengan perencanaan sebelumnya agar anak memiliki kesiapan dalam memasuki pendidikan kejenjang dasar. Pelaksanaan pembelajaran anak usia dini dilakukan melalui bermain secara interaktif, inspiratif, menyenangkan, kontekstual dan berpusat pada anak untuk berpartisipasi aktif serta memberikan keleluasaan bagi prakarsa, kreativitas, dan kemandirian sesuai dengan bakat, minat, dan perkembangan fisik serta psikologis anak (Permendikbud, nomor 137 tahun 2014).

Interaktif merupakan proses pembelajaran yang mengutamakan interaksi antara anak dan anak, anak dan pendidik, serta anak dan lingkungannya. Inspiratif merupakan proses pembelajaran yang mendorong perkembangan daya imajinasi anak. Menyenangkan merupakan proses pembelajaran yang dilakukan dalam suasana bebas dan nyaman untuk mencapai tujuan pembelajaran. Kontekstual merupakan proses pembelajaran yang terkait dengan tuntutan lingkungan alam dan sosial-budaya. Berpusat pada anak merupakan proses pembelajaran yang dilakukan sesuai dengan karakteristik, minat, potensi, tingkat perkembangan, dan kebutuhan anak (Permendikbud, nomor 137 tahun 2014). 
Proses pembelajaran inspiratif memungkinkan siswa untuk mencoba dan melakukan sesuatu. Biarkan siswa berbuat dan berpikir sesuai dengan inspirasinya sendiri, sebab pengetahuan pada dasarnya bersifat subjektif yang bisa dimaknai oleh setiap subjek belajar. Proses pembelajaran menyenangkan dapat dilakukan dengan menata ruangan yang apik dan menarik dan pengelolaan pembelajaran yang hidup dan bervariasi, yakni dengan menggunakan pola dan model pembelajaran, media dan sumbersumber belajar yang relevan (Direktorat Tenaga Kependidikan, 2008).

Seorang guru Pendidikan Anak Usia Dini dituntut untuk bisa menggunakan metode pembelajaran yang memenuhi kebutuhan dan minat anak. Metode pembelajaran memegang peran yang sangat penting. Keberhasilan implementasi strategi pembelajaran sangat tergantung pada cara guru menggunakan metode pembelajaran, karena suatu strategi pembelajaran hanya mungkin dapat diimplementasikan melalui penggunaan metode pembelajaran (Direktorat Tenaga Kependidikan, 2008).

Metode pembelajaran tidak terlepas dari penggunaan media pembelajaran. Pujiati (2003) menyatakan bahwa media alat peraga akan dapat berfungsi dengan baik apabila dapat memberikan pengalaman yang bermakna, mengaktifkan dan menyenangkan anak. Kata media berasal dari kata medium (latin) yang berarti antara. Istilah tersebut menunjukkan segala sesuatu yang membawa atau menyalurkan informasi antara sumber atau pemberi pesan dan penerima pesan (Rumampuk, 1988). Pengertian lain dikemukakan oleh (Djamarah 1995) "media adalah alat bantu apa saja yang dapat dijadikan sebagai penyalur pesan guna mencapai tujuan pembelajaran".

\section{Hasil Penelitian}

Kegiatan awal yang dilakukan adalah mengunjungi PAUD Permata Bunda yang terletak di Nagari Cubadak, Kecamatan Lima Kaum. Peneliti melakukan observasi, dokumentasi dan wawancara dan didapatkan hasil yaitu PAUD Permata Bunda menerapkan beberapa metode pembelajaran dalam menciptakan pembelajaran yang interaktif, inspiratif, menyenangkan, kontekstual, dan berpusat pada anak. Metode-metode pembelajaran tersebut adalah sebagai berikut.

a. Metode Bermain Balok

Dalam metode bermain balok ini media yang digunakan guru adalah balok-balok kecil yang telah tersedia di sekolah dan tersususn rapi di rak balok. Sebelum memulai kegiatan ini guru menjelaskan terlebih dahulu 
mengenai aktifitas yang akan dilakukan dan tata tertib yang harus dipatuhi. Kemudian guru membagi kelompok dan setiap kelompok terdiri dari 2 orang. Setiap kelompok dipersilahkan untuk mengambil balok di rak balok dengan tertib dan mereka bebas membuat apa saja yang terlintas dalam pikiran mereka (Hasil Observasi, 12 April 2016).

Setelah selesai membuat karyanya, guru menanyakan tentang apa yang dibuat anak dan guru menstimulasi anak untuk bercerita tentang hasil karya mereka. Guru selalu memberi reward berupa pujian terhadap hasil karya anak terlepas dari bagus atau tidaknya hasil karya tersebut. Jika hasil karya tersebut masih kurang bagus, guru tetap memberi pujian, akan tetapi dibarengi dengan nasehat dan tuntunan untuk menciptakan karya yang lebih bagus lagi. Selesai melakukan kegiatan anak diminta untuk merapikan kembali balok-balok tersebut dan mengembalikan ke rak balok (Hasil Observasi, 12 April 2016).

Menurut Nelna Amri, S.Pd. (Hasil Wawancara, 18 April 2016) penerapan metode pembelajaran bermain balok dengan media balok akan menambah kreatifitas pada anak usia dini. Penggunaan media balok ini akan memotivasi anak untuk berkreasi membuat apa saja yang terdapat di lingkungan anak, misalnya membuat gedung, meja, kursi, dan sebagainya. Jadi di sini diperlukan stimulasi guru untuk membuat anak-anak lebih kreatif untuk menciptakan hal-hal baru. Dari aktifitas ini juga anak dilatih untuk tanggung jawab dengan merapikan kembali mainan mereka, melatih anak bersosialisasi dan bekerjasama karena mereka terbagi menjadi beberapa kelompok, kemudian melatih anak tenggang rasa karena anak dipersilahkan sendiri mengambil balok sesuai dengan kebutuhan mereka karena anak-anak yang lain juga membutuhkan balok untuk membuat karya masing-masing.

Nelna Amri, S.Pd (Hasil Wawancara, 18 April 2016) menyatakan bahwa ada kelebihan dan kekurangan dari metode bermain balok ini. Kelebihannya adalah anak terstimulasi untuk mengeluarkan ide kreatifnya dan anak juga dapat melihat hasil kreatifitas teman-temannya. Sedangkan kekurangannya adalah dibutuhkan media balok dalam jumlah yang cukup banyak supaya anak berkreasi tanpa batas, sementara ketersedian media balok belum bisa memenuhi tuntutan tersebut.

b. Metode Hafalan

Aktifitas yang dilakukan dalam metode hafalan ini adalah menghafal ayat-ayat Al-Quran dalam surat pendek dan menghafal bacaan shalat. Langkah pertama yang dilakukan guru yaitu mengajarkan surat pendek dan meminta

52 anak untuk menghafalnya di rumah. Guru akan berkomunikasi dengan orang 
tua anak dengan cara mengirim SMS tentang tugas hafalan tersebut. Waktu yang diberikan untuk menyetor ayat tergantung pada panjang pendeknya surat. Apabila surat pendek tersebut terdiri dari beberapa ayat yang panjang maka waktu yang diberikan untuk menghafal selama 2 (dua) sampai 3 (tiga) minggu, tetapi bila surat tersebut terdiri dari beberapa ayat pendek seperti surat Al-Ikhlas, maka waktu yang diberikan untuk menghafal cukup selama 1 (satu) minggu sampai 2 (dua) minggu saja (Hasil Observasi, 19 April 2016).

Selain menghafal di rumah, setiap pagi guru beserta anak akan mengulang bacaan surat pendek selama 2 (dua) sampai 3 (tiga) minggu sampai anak benar-benar hafal, kemudian bagi anak yang sudah mampu menghafal diminta untuk menyetor ayat kedepan kelas dan dikasih reward berupa pujian. Bagi anak yang belum bisa menghafal surat pendek tersebut sampai batas waktu yang telah ditentukan, guru tidak pernah memaksa untuk menghafalnya sampai bisa, tetapi guru berkomunikasi kembali dengan orang tua untuk membimbing anak di rumah. Guru juga tidak lepas tanggung jawab begitu saja, melainkan guru berusaha merangkul anak dan membujuk untuk mengulang hafalannya di sela-sela waktu bermain anak (Hasil Wawancara dengan Nelna Amri, S.Pd, 19 April 2016).

Selain untuk menghafal ayat-ayat Al-Quran, metode hafalan ini juga dipakai untuk membimbing anak dalam menghafal bacaan shalat. Anak diajarkan mulai dari niat shalat, bacaan dalam shalat, sampai pada salam untuk beberapa kali pertemuan. Ketika anak sudah hampir menguasai bacaan tersebut, guru mengajak anak untuk langsung praktek shalat agar anak mengetahui setiap gerakan shalat dan bacaan apa saja yang dibaca pada setiap gerakan. Praktek shalat dilakukan di kelas saja karena PAUD Permata Bunda belum memiliki Mushalla (Hasil Wawancara dengan Nelna Amri, S.Pd, 18 April 2016).

Menurut Amri (Hasil Wawancara, 18 April 2016) kelebihan dalam metode hafalan ini adalah melatih anak dalam mengingat, sedangkan kendala yang dihadapi dalam metode hafalan ini adalah rendahnya peran orang tua dalam membimbing anak di rumah. Walaupun telah dikomunikasikan dengan orang tua tentang tugas hafalan tersebut, tetapi masih ada sebagian kecil orang tua yang mungkin lupa membimbing anak di rumah sehingga ada 2 (dua) atau 3 (tiga) orang anak yang butuh waktu lama dalam menyetor ayat, bahkan kadang tidak tuntas dalam hafalan.

c. Metode Bermain Peran

Metode bermain peran merupakan salah satu kegiatan yang sangat digemari oleh anak. Dalam metode ini anak diajak untuk memerankan 
beberapa pekerjaan yang sudah familiar bagi mereka seperti memerankan petani, dokter, polisi, dan sebagainya. Ketika bermain peran dengan tema petani, anak diajak untuk memerankan seorang pak tani dengan keluarga kecilnya seperti bu tani dan anak petani. Dalam aktivitas ini digambarkan bagaimana seorang petani mempersiapkan peralatan untuk ke kebun atau sawah seperti cangkul, bu tani menyiapkan makanan untuk dibawa ke sawah atau kebun dan anak-anak petani membantu orang tua mereka. Anak-anak sangat antusias memerankan peran mereka masing-masing (Hasil Observasi, 19 April 2016). Dari kegiatan bermain peran ini anak dapat memetik nilainilai positif seperti menghargai pekerjaan seorang petani, makna dari kerja sama, dan kewajiban anak dalam membantu orang tua (Hasil Wawancara dengan Nelna Amri, S.Pd, 18 April 2016).

Begitu juga dengan bermain peran sebagai dokter, ada yang menjadi dokter, perawat, pasien dan jabatan lainnya seperti bagian administrasi Rumah Sakit. Dari kegiatan tersebut guru mengajarkan kepada anak bagaimana bersikap sebagai seorang dokter, perawat atau bagian administrasi dalam melayani orang lain dan bagaimana bersikap sesama pasien yang sedang antri di Rumah Sakit. Banyak nilai-nilai moral yang dapat diajarkan kepada anak melalui metode bermain peran ini jelas Amri (Hasil Wawancara dengan Nelna Amri, S.Pd, 18 April 2016).

Metode bermain peran ini merupakan salah satu kegiatan yang sangat digemari oleh anak, karena dengan metode ini anak bebas mengekspresikan diri, namun guru masih mendapat kendala dalam pelaksanaannya seperti minimnya media bermain peran. Amri (Hasil Wawancara, 18 April 2016) juga menjelaskan bahwa media untuk bermain peran sebagai dokter dan petani cukup lengkap di PAUD Permata Bunda, namun untuk media bermain peran lainnya seperti polisi, nelayan, dan pekerjaan lainnya masih sangat terbatas. Seting ruangan juga kurang memadai untuk metode bermain peran ini. Meskipun begitu guru tetap bersemangat dalam membimbing anak-anak untuk bermain peran.

d. Metode Bermain Musik dan Bernyanyi

Metode bermain musik dan bernyanyi juga termasuk kegiatan yang digemari oleh anak-anak. Dalam kegiatan ini anak-anak diajarkan untuk membuat alat musik perkusi dari gelas yang diisi dengan air. Masingmasing gelas diisi air dengan takaran yang berbeda-beda, ada yang penuh, setengah, sedikit, dan paling sedikit air, nantinya gelas-gelas tersebut akan mengeluarkan bunyi yang berbeda. Kemudian anak juga diajarkan membuat

54 alat musik dari botol air mineral yang diisi dengan batu-batu kecil, sama 
halnya dengan gelas-gelas tadi, botol-botol tersebut juga di isi batu dengan jumlah yang berbeda pula, ada yang banyak dan ada yang sedikit. Dari botolbotol dengan batu yang berbeda-beda tersebut akan menghasilkan bunyi yang berbeda pula. Sebagian anak diberi galon dan kaleng-kaleng bekas yang sudah dibersihkan dan disiapkan untuk media bermain musik dan semua alat tersebut akan mengeluarkan musik tersendiri untuk dinikmti oleh anak dan guru (Hasil Wawancara dengan Bu Nelna Amri, S.Pd, 25 April 2016).

Untuk aktivitas bernyanyi, guru mengajarkan lagu anak-anak dan dinyanyikan secara bersama-sama setiap hari. Bernyanyi ini biasanya dilakukan setelah do'a pagi sebelum mulai pembelajaran dan sebelum mengakhiri pembelajaran atau sebelum pulang sekolah (Hasil Observasi, 26 April 2016). Di sini sangat dituntut kemampuan guru dalam penguasaan lagu anak-anak. Guru harus memiliki banyak referensi lagu anak-anak supaya anak tidak bosan dengan lagu yang itu-itu saja, dan guru juga dituntut untuk kreatif dalam menciptakan syair lagu yang sesuai dengan tema pembelajaran saat itu. Misalnya ketika tema pembelajaran anak tentang profesi atau pekerjaan, maka guru harus bisa membuat lagu sesuai dengan tema tersebut. Nelna Amri, S. Pd (Hasil Observasi, 26 April 2016) mencotohkan sebuah lagu tentang pekerjaan sebagai berikut.

\author{
Pak Dokter kerja di Rumah Sakit \\ Pak Polisi di jalan raya \\ Pak Tani...Pak Tani di sawah \\ Bu Guru...hai...hai...ngajar di kelas
}

Syair lagu ini diciptakan sendiri oleh guru dan untuk iramanya diambil dari irama lagu "Melempar Manggis". Selain bernyanyi guru juga mengajarkan gerakan tangan sehingga bernyanyi menjadi kegiatan yang menyenangkan buat anak (Hasil Wawancara dengan Nelna Amri, S.Pd, 25 April 2016).

Kelebihan dari metode ini adalah bisa memperkaya kosa kata anak, sedangkan kendala yang dihadapi guru dalam metode bermain musik dan bernyanyi ini adalah minimnya ketersediaan alat musik dan referensi lagu anak-anak. Sebagai jalan keluar dari masalah ini guru berusaha menulis syair lagu sendiri, jadi guru harus memiliki motivasi yang kuat dalam menciptakan sebuah lagu untuk dinyanyikan bersama anak. Untuk memainkan alat musik guru bersama anak-anak juga membuat dan menyediakan terlebih dahulu media-media yang akan digunakan untuk bermain (Hasil Wawancara dengan Nelna Amri, S.Pd, 25 April 2016). 
e. Metode Bermain Kartu

Dalam metode bermain kartu ini, guru mengajarkan kepada anak cara membuat kartu berwarna, kartu berbentuk geometri, dan kartu yang ditulis dengan huruf dan angka. Kegiatan membuat kartu ini dilakukan secara bersama-sama, anak dibimbing untuk bisa membuat kartu sendiri. Selesai membuat kartu guru mengajak anak untuk merangkai kata menggunakan kartu, menyebutkan warna kartu dan menunjukkan bentuk geometri (Hasil Observasi, 26 April 2016).

Menurut Amri (Hasil Wawancara, 25 April 2016) mengajarkan suatu materi pelajaran tidak bisa dengan penjelasan secara lisan saja karena anak menginginkan pembelajaran yang bervariasi. Di sini kemampuan kognitif anak dikembangkan melalui media kartu. Anak akan senang belajar bila ada media yang menarik bagi mereka. Dengan media kartu anak bisa mengetahui bentuk-bentuk geometri, berupa lingkaran, segitiga, segiempat, persegi panjang. Anak bisa menyebutkan macam-macam warna, dan merangkai huruf menjadi kata.

Keunggulan dari menggunakan media kartu ini adalah bentuknya menarik, mudah dibuat dan biaya pembuatannya cukup murah. Anakanak akan menjadi kreatif karena dibimbing untuk bisa membuat media pembelajaran sendiri. Sedangkan kendala yang dirasa adalah untuk permainan kartu bergambar terasa masih kalah menarik dengan kartu yang dijual di toko-toko sebagai media bermain. Meskipun begitu guru tetap berusaha untuk meningkatkan keterampilan dalam membuat media pembelajaran khususnya media kartu (Hasil Wawancara dengan Nelna Amri, S.Pd, 25 April 2016).

\section{f. Metode Eksperimen}

Pada metode eksperimen ini guru melakukan kegiatan-kegiatan percobaan seperti percobaan telur tenggelam dan terapung, menakar dan meliter air, menanam jagung, dan lain-lain. Untuk percobaan telur tenggelam dan terapung memanfaatkan alat dan bahan yang ada di sekitar anak di antaranya gelas bening, kayu kecil, air, telur, dan garam. Air dimasukkan ke dalam gelas hingga 2/3 gelas, masukan telur ke dalam gelas berisi air pelanpelan, ambil garam dengan sendok selanjutnya masukkan ke gelas berisi air, aduk pelan-pelan dan anak diminta mengamati dengan seksama. Kemudian guru dan anak menyimpulkan hasil percobaan tersebut (Hasil Observasi, 26 April 2016).

Untuk eksperimen bercocok tanam, anak langsung diajak berkebun di 56 sebelah sekolah bersama-sama guru menanam biji jagung. Dengan metode 
eksperimen ini anak langsung mengerti langkah-langkah yang harus mereka lakukan dalam bercocok tanam atau aktifitas lainnya. Amri (Hasil Wawancara, 25 April 2016) mengatakan bahwa metode eksperimen dapat membantu anak memahami dengan jelas suatu proses dengan penuh perhatian dan guru akan membantu menjelasan kepada anak tentang kesimpulan dari kegiatan-kegiatan yang mereka lakukan. Tujuan dari metode eksperimen ini adalah agar anak mampu secara aktif memahami informasi tentang apa yang ada disekitar lingkungan tempat tinggalnya.

Kelebihan metode eksperimen adalah anak bisa belajar sains dengan menyenangkan, sedangkan kendala yang terasa dalam metode eksperimen ini adalah terbatasnya media dalam melakukan berbagai eksperimen. Guru belum bisa melakukan eksperimen terutama dalam pembelajaran sains layaknya dalam sebuah laboratorium. Tetapi guru selalu berusaha menampilkan eksperimen-eksperimen sepanjang eksperimen tersebut bisa dilakukan dengan media hasil buatan sendiri atau bersama anak (Hasil Wawancara dengan Nelna Amri, S.Pd, 25 April 2016).

Temuan tentang metode pembelajaran PAUD yang mendukung temuan dalam penelitian ini adalah Warniti, dkk (2014) dengan hasil analisis data menunjukan bahwa terjadi peningkatan perkembangan motorik halus anak dengan diterapkannya metode pemberian tugas melalui kegiatan meronce pada hasil penelitian siklus I sebesar 53.95\% yang berada pada kategori sangat rendah ternyata mengalami peningkatan pada penelitian siklus II menjadi $80.7 \%$ yang berada pada kategori tinggi. Pada penelitian siklus I ke siklus II terjadi peningkatan sebesar $26.75 \%$. Dengan demikian dapat disimpulkan bahwa dengan menerapkan metode pemberian tugas melalui kegiatan meronce dapat meningkatkan perkembangan motorik halus pada anak kelompok B Semester II TK Tirta Kumara Payangan tahun pelajaran 2013/2014.

Hasil penelitian Anggreni, dkk (2014) juga mendukung hasil penelitian ini karena terjadi peningkatan kemampuan kognitif sains dalam mencampur warna dengan penerapan metode eksperimen pada siklus I sebesar $40.85 \%$ yang berada pada kategori sangat rendah ternyata mengalami peningkatan pada siklus II menjadi $91.07 \%$ tergolong pada kategori sangat tinggi. Jadi terjadi peningkatan kemampuan kognitif sains dalam mencampur warna pada anak sebesar 40\%. Disimpulkan bahwa penerapan metode eksperimen dapat meningkatkan kemampuan kognitif sains dalam mencampur warna pada anak kelas B3 di TK Titi Dharma Denpasar Tahun Pelajaran 2013/2014. Hal ini dapat dilihat dari peningkatan rata-rata persentase kemampuan 
kognitif sains dalam mencampur warna pada siklus I sebesar $40.85 \%$ menjadi sebesar $91.07 \%$ pada siklus II yang berada pada kategori sangat tinggi.

Temuan penelitian selanjutnya yang mendukung hasil penelitian ini dilakukan oleh Yutiastini, dkk (2014) yang menemukan hasil bahwa terjadi peningkatan perkembangan kognitif anak dalam pengenalan lambang bilangan kelompok B1 dengan media kartu angka bergambar pada siklus I sebesar $56.50 \%$ berada pada kriteria rendah dan pada siklus II meningkat menjadi sebesar $81.50 \%$ berada pada kriteria tinggi. Peningkatan perkembangan kognitif berbantuan media kartu angka bergambar dari siklus I sampai siklus II sebesar 25\%.

Hasil penelitian berikutnya yang mendukung hasil penelitian ini dilakukan oleh Nonik, dkk (2013) yang menunjukkan bahwa terjadi peningkatan kemampuan kognitif pada anak semester II Tahun Ajaran 2012/2013 di PAUD Widya Dharma Bondalem. Hal ini terlihat dari peningkatan kemampuan kognitif pada siklus I adalah $55.56 \%$ menjadi $70.67 \%$ pada siklus II. Jadi terjadi peningkatan sebesar 15.11\%. Berdasarkan hasil tersebut dapat disimpulkan bahwa penerapan metode demonstrasi dengan media kartu gambar mampu meningkatkan kemampuan kognitif anak kelompok A PAUD Widya Dharma Bondalem Kecamatan Tejakula, pada Semester II Tahun Ajaran 2012/2013.

Hasil penelitian Risanti, dkk (2013) juga mendukung hasil penelitian ini karena adanya peningkatan perkembangan sosial emosional anak kelompok A melalui kegiatan finger painting berbantuan media konkrit pada siklus I sebesar 55.5\% pada kategori rendah dan meningkat pada siklus II menjadi 81.9\% berada pada kategori tinggi. Dari siklus I ke siklus II meningkat sebesar $26.4 \%$. Kemudian penelitian yang dilakukan oleh Andari (2013) juga mendukung kajian ini, penelitiannya menemukan hasil bahwa terjadi peningkatan minat belajar anak di PAUD terdapat $74 \%$ anak yang memiliki minat belajar tinggi, $21.33 \%$ anak yang memiliki minat belajar sedang, dan $4.67 \%$ anak yang memiliki minat belajar rendah. Berdasarkan hasil pengamatan tersebut, jelas sekali membuktikan bahwa penggunaan metode demonstrasi sangat berperan dalam meningkatkan minat belajar anak.

\section{Simpulan}

Kesimpulan dalam penelitian ini adalah metode pembelajaran yang 58 digunakan di PAUD Permata Bunda 1) metode bermain balok; 2) metode 
hafalan; 3) metode bermain peran; 4) metode bermain musik dan bernyanyi; 5) metode bermain kartu; dan 6) metode eksperimen. Dari kesimpulan tersebut guru harus memiliki motivasi yang kuat untuk meningkatkan pengetahuan dalam menciptakan media-media pembelajaran yang kreatif demi terlaksananya metode pembelajaran yang telah disusun. 


\section{DAFTAR PUSTAKA}

Agustina, Atik. Retnowati, Tri Hartiti. 2013. “Evaluasi Pelaksanaan Pembelajaran Program Pendidikan Anak Usia Dini (PAUD) di Kecamatan Trucuk Kabupaten Klaten". Jurnal Evaluasi Pendidikan Volume 1, No 2, 2013. Prodi Penelitian dan Evaluasi Pendidikan PPs UNY Universitas Negeri Yogyakarta.

Anggreni, I Gusti Ayu Inten. Suara, I Made. Wiyasa, I Komang Ngurah. 2014.

"Meningkatkan Kemampuan Kognitif Sains Dalam Mencampur Warna Melalui Penerapan Metode Eksperimen Pada Anak Kelompok B". e-Journal PG-PAUD Volume 2 No 1 Tahun 2014. Universitas Pendidikan Ganesha.

Andaril, Nyoman Deni Setia. 2013. "Peranan Metode Demonstrasi Dalam Meningkatkan Minat Belajar Anak Di Kelompok B TK Dharma Santi Desa Tolai Barat Kecamatan Torue Kabupaten Parigi Moutong". Jurnal PG PAUD, No. Stambuk: A 41109 017. Universitas Tadulako.

Agung, A.A.Gede. 2012. Metodologi Penelitian Pendidikan. Singaraja: Undiksha Singaraja.

Direktorat Tenaga Kependidikan. 2008. "Strategi Pembelajaran dan Pemilihannya untuk kompetensi supervisi akademik". Direktorat Jendral Peningkatan Mutu Pendidik dan Tenaga Kependidikan Departemen Pendidikan Nasional.

Djamarah, S.B. 1995. Strategi Belajar Mengajar. Jakarta. PT Rineka Cipta.

Emzir. 2011. Metodologi Penelitian Kualitatif: Analisis Data. Jakarta: PT Raja Grafindo Persada.

Hasan Maimunah. 2009. Pendidikan Anak Usia Dini. Jogjakarta: DIVA Press. Isjoni. 2010. Model Pembelajaran Anak Usia Dini. Bandung: Alfabeta.

Kemdikbud. 2016. "Bersinergi Samakan Persepsi Pengelolaan BOP DAK PAUD” http://www.paud-dikmas.kemdikbud.go.id/berita/8469.html 24 April 2016.

Moleong, Lexy J. 2005. Metodologi Penelitian Kualitatif. Bandung: Remaja Rosda Karya.

Mutiah, Diana. 2010. Psikologi Bermain Anak Usia Dini. Jakarta: Prenada Media.

Moeslichatoen. 2004. Metode Pengajaran di Taman Kanak-kanak. Jakarta: PT Cipta.

60 Martini, J. 2006. Perkembangan Pengembangan Anak Usia Taman Kanak- 
Kanak: pedoman bagi orang tua dan guru. Jakarta: PT Grasindo.

Nonik, Ni Nyoman. Raga, I Gede. Murda, I Gede. 2013. "Penerapan Metode

Demonstrasi Dengan Media Kartu Gambar Untuk Meningkatkan

Kemampuan Kognitif Anak Kelompok A Di PAUD Widya Dharma Bondalem Tejakula". Jurnal Pendidikan Guru Universitas Pendidikan Ganesha.

Prasetyo, Agung. Yulianti, Fitri. Diah, Kenfitria. Octavia, Nurul. 2011. "Analisis Kemampuan Penguasaan Kosakata Baru Pada Anak Pos PAUD Mutiara Semarang Melalui Metode Glenn Doman". Jurnal Penelitian PAUDIA, Volume 1 No. 1.

Risanti, Ni Made Nita. Wirya, I Nym. Wiarta, I Wyn. "Penerapan Metode Pemberian Tugas Berbantuan Media Konkrit Melalui Kegiatan Finger Painting Untuk Meningkatkan Perkembangan Sosial Emosional". Jurnal Pendidikan PAUD Universitas Pendidikan Ganesha.

Permendikbud Nomor 137 Tahun 2014. 2014. Salinan Peraturan Menteri Pendidikan Dan Kebudayaan Republik Indonesia Nomor 137 Tahun 2014 Tentang Standar Nasional Pendidikan Anak Usia Dini.

Permendikbud Nomor 13 Tahun 2015. 2015. Salinan Peraturan Pemerintah Republik Indonesia, Nomor 13 Tahun 2015 Tentang Perubahan Kedua Atas Peraturan Pemerintah Nomor 19 Tahun 2005 Tentang Standar Nasional Pendidikan.

Rumampuk, D,B. 1988. Media Instruksional IPS. Jakarta: Proyek Pengembangan Lembaga Kependidikan Depdikbud.

Sanjaya, Wina. 2007. Strategi Pembelajaran. Jakrta: Kencana.

Sari, Yulia. 2012. "Peningkatan Kemampuan Sains Anak Usia Dini Melalui Metode Demonstrasi di Taman Kanak-Kanak Tri Bina Payakumbuh". Jurnal Pesona PAUD, Vol 1: No 1 Universitas Negeri Padang.

Sulhan, Najib. 2006. Pembangunan Karakter Pada Anak. Surabaya: Intelektual Club.

Slameto. 2010. Belajar dan Faktor-faktor yang Mempengaruhinya. Jakarta: PT Rineka Cipta.

Sukmadinata, Syaodih Nana. 2006. Metode Penelitian Pendidikan. Bandung: Remaja Rosda Karya.

Suharti. 2013. "Manajemen Pendidikan Anak Usia Dini (PAUD Dalam Rangka Meningkatkan Mutu Pembelajaran (Studi Perbandingan Pada PAUD Terpadu Negeri Pembina dan PAUD Robby Roddiyah Kabupaten Rejang Lebong". Universitas Bengkulu: S2 Thesis. 
Sinaga, Syahrul Syah. 2010. "Pemanfaatan Dan Pengembangan Lagu AnakAnak Dalam Pembelajaran Tematik Pada Pendidikan Anak Usia Dini/ TK". Journal of Arts Research Education Universitas Negeri Semarang.

Warniti, Surya, Ardana, Ketut, Kristiantari, Rini, Penerapan Metode Pemberian Tugas Melalui Kegiatan Meronce Untuk Meningkatkan Perkembangan Motorik Halus Anak Kelompok B, e-Journal PGPAUD Universitas Pendidikan Ganesha, Volume 2 No 1 Tahun 2014, Jurusan Pendidikan Guru Pendidikan Anak Usia Dini, FIP Universitas Pendidikan Ganesha Singaraja, Indonesia.

Yutiastini, Ni Luh Putu. Wirya, I Nyoman. Asril, Nice Maylani. 2014. "Penerapan Metode Pemberian Tugas Berbantuan Media Kartu Angka Bergambar Untuk Meningkatkan Perkembangan Kognitif Anak Usia Dini". e-Journal PG-PAUD Universitas Pendidikan Ganesha Volume 2 No 1 Tahun 2014. 